\section{Una nueva revista de salud pública para las Américas}

En 1922 la Oficina Sanitaria Panamericana inició la publicación mensual de una de las primeras revistas técnicas dedicadas a la salud pública internacional: el Boletín de la Oficina Sanitaria Panamericana. En 1966 se empezó a publicar una selección de artículos del Boletín traducidos al inglés y unos años más tarde se lanzó como revista trimestral regular el Bulletin of the Pan American Health Organization. Al pasar de los años, en las páginas de las dos revistas se han registrado fielmente los avances y disyuntivas de la salud pública en la Región de las Américas, así como la historia de nuestra Organización. El presente número inaugural de la Revista Panamericana de Salud Pública/Pan American Journal of Public Health brinda un nuevo nombre y nuevas perspectivas al Boletin y el Bulletin, que ahora se fusionan en una sola revista para responder a las expectativas de los lectores y representar mejor la realidad plurilingüe de la Región.

La nueva y más grande revista continuará el trabajo de las dos publicaciones, pero también acogerá información sobre recursos humanos y epidemiología que habría aparecido en Educación Médica y Salud y otras ediciones periódicas de la OPS que han dejado de publicarse. Los artículos seleccionados por arbitraje, que contribuyen expertos en salubridad y otros científicos de los países de las Américas y distintas regiones del mundo, seguirán constituyendo una sección sustancial de la revista. Según las preferencias expresadas por nuestros lectores, se mantendrán también otras secciones mensuales y ocasionales de las que ahora disfrutan.

La decisión de publicar en un idioma u otro se hará, no en función de la lengua del manuscrito original, sino de la proporción del público para el cual tenga mayor interés científico y posibilidades de aplicación. Cuando se considere apropiado, habrá artículos que se publicarán en dos idiomas, uno de ellos el inglés, en distintos números de la revista. Los artículos contarán con dos resúmenes informativos, uno en el idioma del artículo (español o portugués) y otro en inglés, y podrán aparecer trabajos en cualquiera de esos idiomas en todas las secciones de la revista. La distribución de revistas a los suscriptores actuales del Boletín y Bulletin continuará sin interrupción. Como en el caso de esas periódicas, se podrá acceder a la tabla de contenido y los resúmenes de la nueva revista por medio del sitio de la OPS en la World Wide Web y es probable que se aumente la presencia de la nueva revista en Internet.

Los objetivos fundamentales de la nueva revista son, por un lado, contribuir a que los profesionales de salud de la Región se mantengan informados de los perfiles y tendencias de salud de los países, estimular la investigación y la divulgación de actualidades de salud nacionales, servir de vehículo idóneo para que los científicos publiquen sus estudios, y seguir siendo la fuente de información sobre salud más extensamente consultada y citada en los países de las Américas. Por otra parte, queremos dar a conocer las actividades y prioridades de la Organización Panamericana de la Salud, según las determinan las orientaciones estratégicas y las líneas principales de cooperación con los Estados Miembros.

La OPS invita a todos los profesionales de salud de las Américas a colaborar con sus comentarios y sobre todo con sus manuscritos a la nueva Revista Panamericana de Salud Pública/Pan American Journal of Public Health, cuya meta cardinal es participar en el mejoramiento de la salud y el bienestar de los pueblos de las Américas. 


\section{A new public health journal for the Americas}

In 1922 the Pan American Sanitary Bureau began publication of the monthly Boletín de la Oficina Sanitaria Panamericana, one of the earliest technical journals dedicated to international public health. Selected articles from the Boletin began to appear in English translation in 1966, and a few years later the Bulletin of the Pan American Health Organization was launched as a regular quarterly journal. Throughout the years, the pages of both journals have constituted a record of the challenges and advances in public health in the Region of the Americas, as well as a history of our Organization. This inaugural issue of the Revista Panamericana de Salud Pública/Pan American Journal of Public Health brings a new name and new perspectives to the Boletin and Bulletin, which now merge to reflect current readership needs and to better embody the multilingual reality of the Region.

The new, larger journal will not only continue the work of both publications, but also will include human resources and epidemiological information which would have appeared in Educación Médica y Salud and other PAHO periodicals that are now discontinued. Peer-reviewed articles contributed by public health experts and other scientists from all parts of the Americas, as well as from other regions of the world, will still constitute a major section of our journal. Complying with the expressed needs of our readership, other monthly and occasional sections now enjoyed by Boletin and Bulletin readers will also remain part of the new journal.

The decision on which language to use for each item published will not be based on the original manuscript's language, but rather on the segment of the public for which it holds greatest scientific interest and practical application. When appropriate, an article may be published in two languages - one of them English - in different issues of the journal. All articles will have two informative abstracts, in English and either Spanish or Portuguese, and each section of the journal may include works in those three languages. Distribution to current recipients of either the Bulletin or Boletin will not be interrupted. As is presently the case for those periodicals, the table of contents and abstracts for the new journal will be available on-line through PAHO's World Wide Web site, and the journal's presence on the Internet may be augmented in the future.

Our new journal's basic objectives are, on the one hand, to help the Region's public health professionals keep abreast of health profiles and trends in the countries, to encourage research on and reporting of current national health issues, to serve as an appropriate vehicle for scientists to publish their findings, and to remain the most widely consulted and cited source of health information on the countries of the Americas. On the other hand, we wish to make known the activities and priorities of the Pan American Health Organization, as determined by its strategic orientations, and its main lines of cooperation with the Member States.

PAHO calls on all health professionals of the Americas to contribute their comments and, above all, their manuscripts, to the new Revista Panamericana de Salud Pública/Pan American Journal of Public Health, whose overriding goal is to play a part in improving the health and well-being of the peoples of the Americas.

SIR GEORGE ALLEYNE DIRECTOR 